\title{
Business Model Development of PT. XYZ Using Business Model Canvas
}

\author{
Jasnovaria Jasnovaria*, Ningky Sasanti Munir \\ Sekolah Tinggi Manajemen PPM \\ Jakarta, Indonesia \\ *jasnovaria13@gmail.com
}

\begin{abstract}
Changes in external and internal environment often cause changes in a company's business model. The business model currently used by PT. XYZ is not able to overcome the main problems such as falling income and increasing costs significantly which resulting a very high negative profits. The right business model design is needed to encourage PT. XYZ to get out of the problem and able to improve its performance so that it needed several research objectives to address the problems that occurred such as identification of the company's vision, mission and goals, identification of elements in the current company's Business Model Canvas, identification of external and internal factors of the company that could affect the elements in the Business Model Canvas as well as the development of the company's Business Model Canvas to improve business performance. The methodology or type of research used is qualitative business research with a business model canvas approach that is equipped with a SWOT analysis and blue ocean strategy and data collection methods through document studies and interviews. From this study, the results of the mapping of 9 (nine) elements of the business model canvas include customer segments, value propositions, channels, customer relationships, revenue streams, key resources, key activities, key partnerships, and cost structures are obtained. The company's external and internal environment is very influential to the elements in the canvas of PT. XYZ. Development of a business model canvas for PT. XYZ has been composed by taking into account the vision, mission, corporate objectives and business strategy which is implemented in 2019 to solve liquidity, profitability and solvency problems and add value innovation to strengthen the canvas elements of the business model especially in the revenue stream and cost structure so as to increase value propositions and value creation in carrying out company operations.
\end{abstract}

Keywords—design of business models, business models canvas

\section{INTRODUCTION}

Indonesia as one of the countries with high economic growth in Asia, has tremendous long-term growth potential. With Indonesia's population up to 265.4 million people, where $60 \%$ of them are under 35 years old and has stable economic conditions, Indonesia is also expected to be one of the strengths of the world economy in 2030 and was on top 5 rank of countries with the highest GDP [1]. Market opportunities of life insurance in Indonesia will be elaborated based on several interpretations of data as outlined below:

\section{A. Life Insurance Industry Overview}

Life insurance premium income in the second quarter 2018 reached 93.5 trillion rupiahs, an increase of 5.5 percent compared to the previous year at same period or a year-on-year (yoy). The achievement was triggered by the stretched of new business premiums. Total premium income was the biggest contributor to total revenue in the life insurance industry, which amounted to 104.3 percent, according to Chairman of the Life Insurance Association of Indonesia (AAJI). Aside from new business premiums, total income of continued premium also sustained the premium as it grew for 2.4 percent to 33.73 trillion rupiahs in the second quarter of 2018 from 32.93 trillion in the second quarter 2017. The overall premium income grew due to corporation network with banks (bancassurance) with the increasing of 9.5 percent yoy and contributing of 44.9 percent of total premium income of 93.5 trillion rupiahs. Agency channel grew to 9.9 percent yoy, contributed for 39.3 percent, and alternative distribution fell 12.2 percent (yoy) with a contribution of 15.9 percent. Agency channel also supported for coffers new business premiums worth of 59.8 trillion rupiahs. Meanwhile new business premium was supported by the increase of agency distribution channel performance for 27.9 percent and the bancassurance channel for 8.5 percent, with each of it gave contribution for 27.5 percent and 55.7 percent of the new business premium. The Growth of Life insurance industry until the second quarter of 2018 was still driven by investment-related insurance product (unit-linked) which contributed 59.5 percent of the total premium income of 93.5 trillion rupiahs. Meanwhile, traditional products contributed 40.5 percent of total premiums. Total investment in the second quarter 2018 grew by 2.4 percent to 445.83 trillion rupiahs [2].

\section{B. Positive Growth of Life Insurance Premium in Indonesia}

Life insurance premium growth in Indonesia has a positive trend with growth based on CAGR (Compound Annual Growth Rate) of $13.85 \%$, as seen in Figure 1. Compared to the growth of the global life insurance industry in the period 20112016 amounted to $10.05 \%$ (Institute Swiss Re, sigma No $3 / 2017$ ) indicates that Indonesia has a better CAGR growth. In addition, based on analysis of AAJI (Indonesia Life Insurance Association) it is predicted that the projections of the life insurance industry in Indonesia promises excellent prospects in the future. Experience so far proves that under normal economic conditions, the life insurance industry continues to grow. As for the growth was estimated approximately in between $10 \%$ to $30 \%$. 


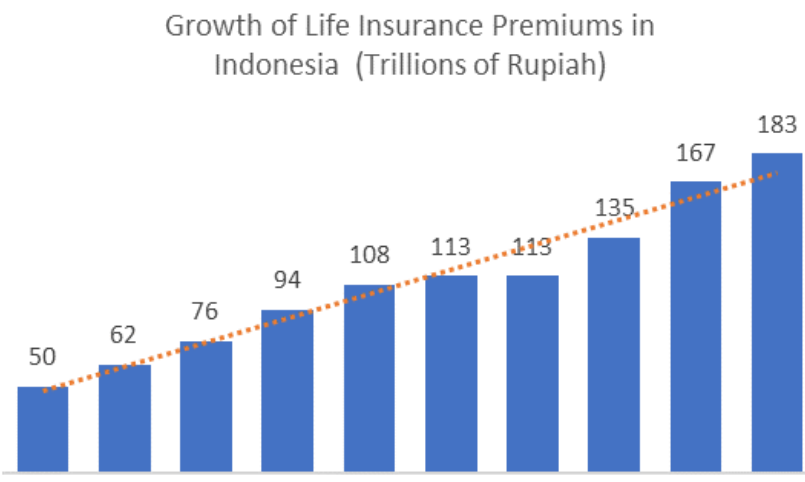

$20082009201020112012 \quad 2013 \quad 2014201520162017$

Source: Life Insurance Association of Indonesia (AAJI)

Fig. 1. Growth of life insurance premium in Indonesia.

\section{Life Insurance Penetration in Indonesia}

Penetration of life insurance to gross domestic product in Indonesia from 2008 to 2017 can be described in figure 2 .

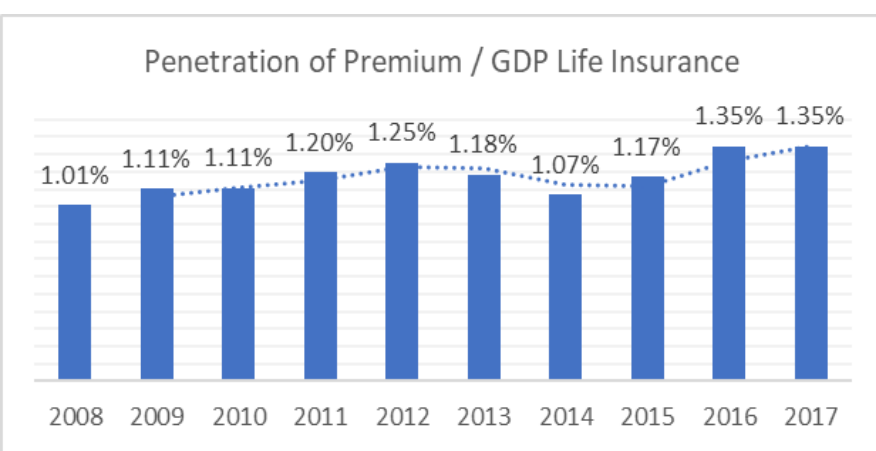

Source: Life Insurance Association of Indonesia (AAJI)

Fig. 2. Life insurance penetration in Indonesia.

And in 2015, the penetration of life insurance to the gross domestic product in ASEAN can be illustrated in figure 3 .

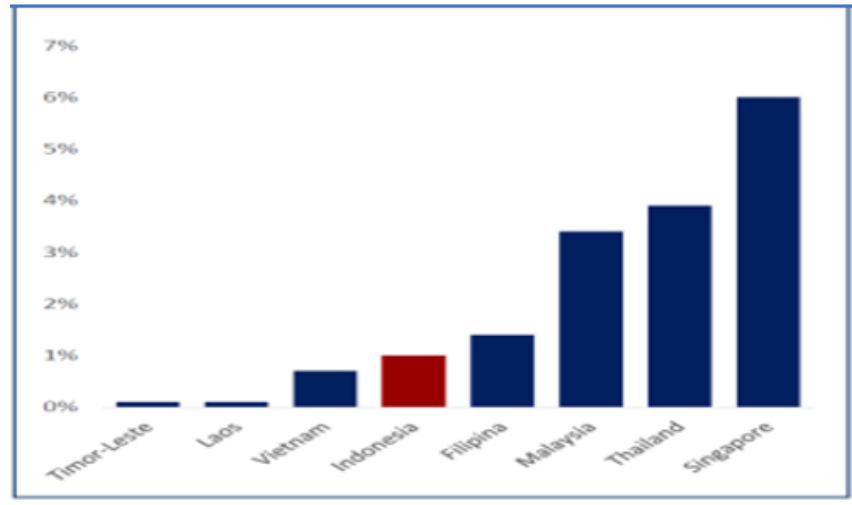

Source: Life Insurance Association of Indonesia (AAJI)

Fig. 3. Life insurance penetration in Asean 2015

In terms of penetration, by comparing the ratio of premiums and gross domestic product (GDP), life insurance in Indonesia still has a large market opportunity indicated by the low level of penetration of life insurance in the last 10 years recorded still remained below 2\%. By comparison in 2015, life insurance penetration in Indonesia is still lower than the ASEAN countries such as the Philippines, Malaysia, Thailand and Singapore. This low penetration rate may indicate that the chances of the life insurance market in Indonesia is still very large in order to be optimized.

Based on figure 1, figure 2 and figure 3 above show that the life insurance industry in Indonesia in 2008 until 2017 and positive growth is still wide open for opportunities to expand market share in the future. But in 2017 until the year 2018, PT. $\mathrm{XYZ}$ which is one of the largest life insurance company in Indonesia decreased performance is very significant, it is illustrated in table 1 and table 2 .

\section{1) Company premium income}

TABLE I. Preming InCOME Statement YeAR 2014-2018 (In Millions)

\begin{tabular}{|c|c|c|c|c|c|c|c|}
\hline INFORMATION & 2014 & 2015 & 2016 & 2017 & 2018 & Average & $\%$ \\
\hline \multicolumn{8}{|l|}{ Premium Income: } \\
\hline $\begin{array}{l}\text { - Premium Income New Business } \\
\text { (NB) Periodic }\end{array}$ & 531.697 & 1.088 .542 & 599.893 & 586.234 & 631.266 & 687.526 & $4,68 \%$ \\
\hline $\begin{array}{l}\text { - Premium Income New Business } \\
\text { (NB) Simultaneously }\end{array}$ & 4.559 .589 & 7.796 .434 & 16.137 .151 & 19.775 .192 & 8.437 .729 & 11.341.219 & $77,23 \%$ \\
\hline - Premium Income Old Business (OB) & 1.089 .847 & 1.258 .897 & 1.204 .978 & 1.434 .550 & 1.530 .519 & 1.303 .758 & $8,88 \%$ \\
\hline Total Premium Income & 6.181 .133 & 10.143 .873 & 17.942 .022 & 21.795 .976 & 10.599 .514 & 13.332 .504 & $90,79 \%$ \\
\hline Income Investment & 1.541 .054 & 913.515 & 3.181 .280 & 3.512 .084 & $(2.788 .379)$ & 1.271 .911 & $8,66 \%$ \\
\hline $\begin{array}{l}\text { Revenue Return on Pension Fund } \\
\text { Services }\end{array}$ & 8.054 & 13.074 & 17.073 & 14.000 & 10.858 & 12.612 & $0,09 \%$ \\
\hline Other income & 60.984 & 57.134 & 13.517 & - & 207.582 & 67.843 & $0,46 \%$ \\
\hline Total income & 7.791 .225 & 11.127 .596 & 21.153 .892 & 25.322 .060 & 8.029 .575 & 14.684 .870 & $100,00 \%$ \\
\hline
\end{tabular}




\section{2) Company expenses}

TABLE II. COMPANY EXPENSES YeAR 2014-2018 (IN MiLLIONS)

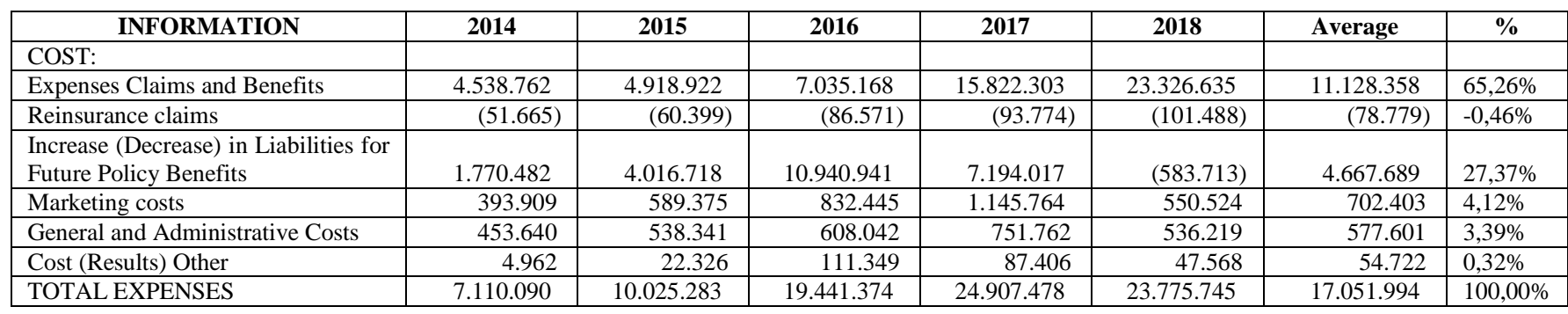

Of premium income statement in table 2 above shows that there has been a decrease in premium income of $\mathrm{Rp} 21.75$ trillion in 2017 to $\mathrm{Rp} 10.59$ trillion in 2018. In addition, an increase in claims expenses from 2017 to 2018, amounting to $\mathrm{Rp} \mathrm{15,82}$ Trillion in 2017 increased to $\mathrm{Rp} 23.32$ trillion in 2018 , as presented in table 2 . in addition, there are also the conditions faced by PT. XYZ in 2018 and still continues to this day, namely:

- Liquidity of investment assets that do not fit with the portfolio of reserves (of asset liability mismatch)

- negative spread due to the products sold have a warranty rate that exceeds the return on investment

- negative cashflow which results from the high melting investment benefits policy of insurance products and savings plan.

- Conditions and minuses negative equity ratio of riskbased capital (RBC).

Related to the above condition of the company, there was a business process that was not running as it should. 3 (three) major business units in the company has not run a control function in maintaining business continuity of the company, this can be illustrated in figure 4 .

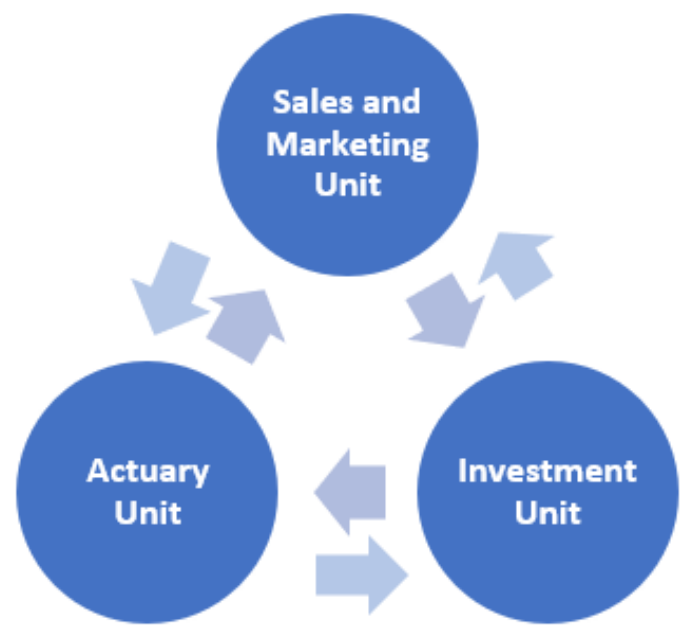

Fig. 4. Relationship between corporate business unit to keep corporate business continuity.

The products have been sold should be evaluated jointly by the three business units of the company, the policy benefits of the products have been sold must be backed up by investment assets (asset liability matching) and unit profitability actuarial analysis of the products that have been sold.

From the explanation in Figure 4 and consider the condition of the company now looks that the company experienced difficulties in managing its business. The business model used at this time has not been able to overcome the major problems such as falling revenues and rising costs significantly resulting in a very high negative profit. the problem of company's products today is the saving plan product sold in Bancassurance distribution channel. Product saving plan is a product similar to bank deposit products were added to the insurance benefit and the product is the company's flagship product, contributing $80 \%$ of its premium income from the year 2013 until 2017. On October 10, 2018 delay in the payment of claims amounting to $\mathrm{Rp} 802$ billion for the plan saving products that have an impact on the company's reputation. As a result of these problems, the Ministry of SOEs as shareholder authority has made several times the turn of the Board of Directors to be able to solve the problems of the company. Board of Directors (BOD) appointed by the Ministry of SOEs on November 2018 has a good capability to fix the problems experienced in managing investment companies for banking and insurance business, at the moment is going transformation of the organization to be able to overcome these problems. Ministry of SOEs as the authority of shareholder has made several times of the turnover of the Board of Directors to be able to solve the problems of the company. Board of Directors (BOD) appointed by the Ministry of SOEs on ng investment companies for banking and insurance business, at the moment is going transformation of the organization to be able to overcome these problems. Ministry of SOEs as shareholder authority has made several times the turn of the Board of Directors to be able to solve the problems of the company. Board of Directors (BOD) appointed by the Ministry of SOEs on November 2018 has a good capability to fix the problems experienced in managing investment companies for banking and insurance business, at the moment an organization transformation is on process in order to overcome these problems.

From the company's age, PT. XYZ is a company that has been long operating in Indonesia for 159 years old. 159 years have passed with a variety of problems, but fundamentally the organization always dealt with problems when a change in management was occurred so a value creation is desperately needed in running the company's in order to strengthen the organization's fundamental and guaranteed of continuity of company's business. 
With the complexity of the company's problems, a business model that could map and provide solutions is needed to improve revenue performance and cost control so a value proposition is created that can improve company's business performance and the business model framework in accordance with this is the Business Model Canvas. The purpose of this study is to obtain the right business model for PT. XYZ to improve its business performance.

\section{LITERATURE REVIEW}

\section{A. Business Model Canvas}

Business model canvas, hereinafter referred as BMC, was first introduced by Alexander Osterwalder [3]. BMC is a means of visual 1 a page that contains nine areas of the business model, namely Customer Segments, Value propositions, Channels, Customer Relationship, Revenue Streams, Key Activities, Key Resources, Key Partners, Cost Structure as shown in figure 5.

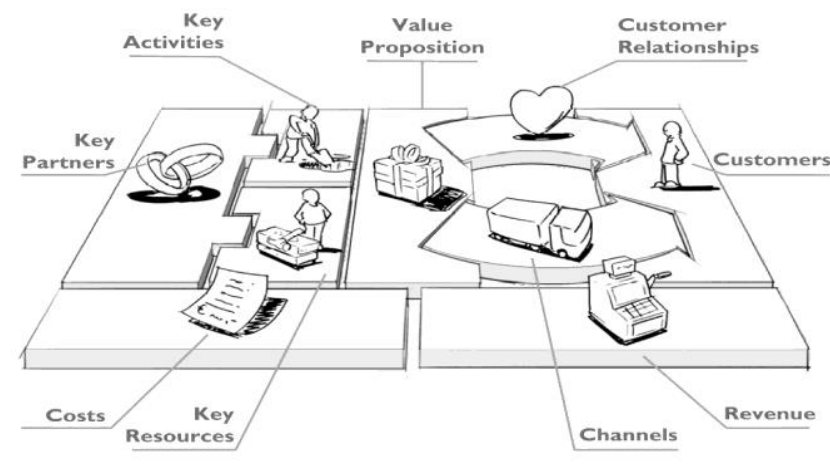

Fig. 5. Business model canvas.

\section{B. Customer Segment}

Customer Segment describes specific customer segmentation which became business target. Segmentation can be selected based on an economic level, age, specific community, or specific behavior of consumers. Segmentation is necessary to understand and capture the specific needs of the targeted consumer.

\section{Value Proposition}

Value Proposition describes the benefits or will be obtained by consumer when choosing a product that is offered compare to select another similar product / services. In other words, the Value Proposition describes the strength or the excellence of a product / service that is offered.

\section{Channel}

Channel is a proper way to be used in delivering business value proposition to consumers. Companies should choose the right channel in order to aim the targeted consumers as the planned. The more creative in creating distribution channel will result greater opportunities to be on top of the competition.

\section{E. Customer Relation}

Customer Relationship is a way or used to keep in touch and strengthen the relationship with the consumer. This must be done so the customer's number will keep growing and to maintain customer loyalty.

\section{F. Revenue Stream}

Revenue Stream describes about how the Company generates money. In business, having a clear and sensible revenue stream (revenue streams) is important to keep the business alive.

\section{G. Key Resources}

Key Resources are the key resource or the main that musthave so the key business activities can be carried out and the value proposition can be given to the consumer. Key resources are the most important asset that enables the business model can work well.

\section{H. Key Activities}

Key Activities describe the activity list of what should be done in the business, both main and supporting activities. On a sheet of key activities will also be seen alse-the amount of human resources and managerial time required in the process.

\section{Key Partners}

Key Partners describe the parties that were involved in the cooperation to support and optimize the allocation of resources, reduce the risk and uncertainty of competition, as well as improving performance. The aim is to cooporate with business partners to get a cheap price and reduce the risk of unavailability of resources that are not owned.

\section{J. Cost Structure}

Cost Structure describes the expenses incurred for business financing. The business financing such as human resources costs, telephone costs, operating costs, taxes and so forth.

\section{K. Blue Ocean Strategy on the Business Model Canvas}

Blue ocean strategy launched by Kim and Mauborgne in 2005 [4]. The blue ocean strategy is a powerful method to reassess the value proposition and business model as well as explore new customer segments. To realize the value of innovation, Kim and Mauborgne proposed an analytical tool called the four actions framework as shown in figure 2.5 [4]. The Four key questions asked the logic of industry strategies and business models that have been established, as the following:

- What factors that are considered available in the industry need to be eliminated?

- What factors that should be reduced until slightly below the industry standard?

- What factors that should be raised until above the industry standard?

- What factors that should be created that was never be offered in the industry?

In addition to value innovation, Kim and Mauborgne proposed to explore the non-customers to create a market that no competitor and grasp an untapped market. 
The framework of four actions can be seen in figure 6 .

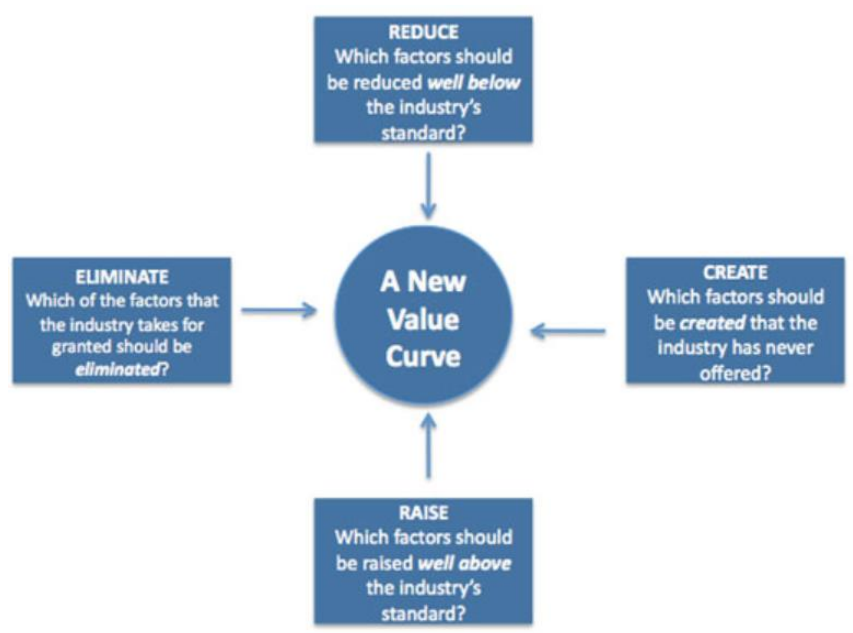

Fig. 6. Four actions framework.

Combines the concept of value innovation of Kim and Mauborgne and frameworks four acts with a business model canvas creating new tools that are very precise. In the business model canvas, the right side represents the creation of value and the left side represents the cost. It is an excellent fit with the logic of value innovation Kim and Mauborgne on value enhancement and cost reduction as in figure 7.

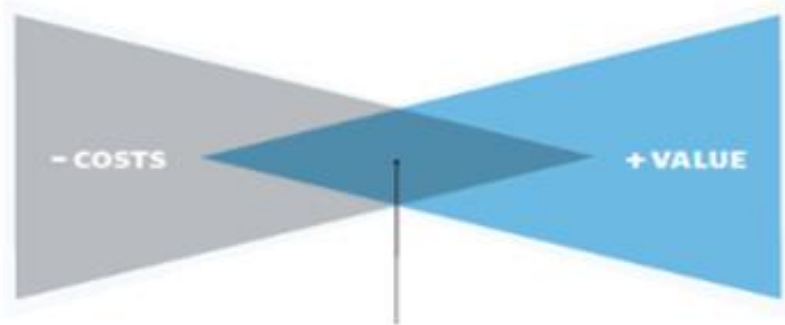

VALUE INNOVATION

Fig. 7. Innovation value.

\section{RESEARCH METHODS}

This type of research is qualitative business research which is a research that discuss business goal through a technique that allows researchers to provide interpretation of complex phenomena without depending on numerical measurements, the focus is to find the ideal meaning and new insights or new ways. In addition, this thesis is also a strategic plan aimed to arrive at a decision in the company's managerial, supported by analysis and logical argument in exploring the data and information. This research is restricted to the design and development of a Business Model Canvas on PT. XYZ from 2020-2022 by using 9 (nine) elements of Business Model Canvas and developed by adding element of value innovation in order to create Business Model Canvas which could improve company performance with period of observation between 15 th May 2019 until 31st July 2019. The Type of datas that were taken for this research came from 2 data resources, which are :

- Primary data were obtained from the results of informal interviews with the company's management acting as strategic decision makers. The informal interviews contain sequence of questions and statements required in analyzing the data.

- Secondary data were obtained from internal data or documents of the company. other than that, it also used other supporting datas such as scientific journals, articles, research reports, books, and sources from Internet-related research topics.

The datas and informations used in the research business model canvas is obtained from various sources, namely:

- Internal sources, i.e. datas that were obtained from internal sources such as financial data, the company's business plan, operational data, investments, actuarial, product and the results of interviews and interviews with company management.

- External sources, i.e. datas that were obtained from sources outside the company such as data from previous studies, the results of the census of BPS, literature, scientific journals and others.

The analytical framework described in terms of flow and problem solving process. It describes the framework, process and output of work that should be done. Steps in this study are summarized in Figure 8. The appropriate analytical framework analysis framework in Figure 8 can be explained through the main points of discussion as follows:

\section{A. Analysis of the Vision, Mission and Objectives of the Company}

In this section will be analyzed of the Vision, Mission and Objectives of the Company which will be used as a Key Performance Indicator (KPI) management.

\section{B. Explanation of the Elements in the Company's Business Model Canvas}

This section will be explained the elements in Business Model Canvas of current company that includes the nine elements of the business model, such as: customer segments, value propositions, channel, customer relations, resources, key resources, core activities, key partners and the cost structure.

\section{Environmental Analysis Business Model}

Environmental analysis is done by doing macro analyzing using Pestle analysis, analysis of industry characteristics where the company runs its business by using Porter's five forces analysis, using SWOT analysis to determine the strengths, weaknesses, opportunities and threats that will be faced by the company that its effects on Business Model Canvas element are known.

\section{Development of a Business Model Canvas Analysis}

In this section will be explained the development of a Business Model Canvas analysis by adding the value of innovation in the Business Model Canvas aligned with the visions, missions and objectives of the company.

Output of the whole process within the framework of the analysis of this thesis is a form of company business model design that can improve business performance. 


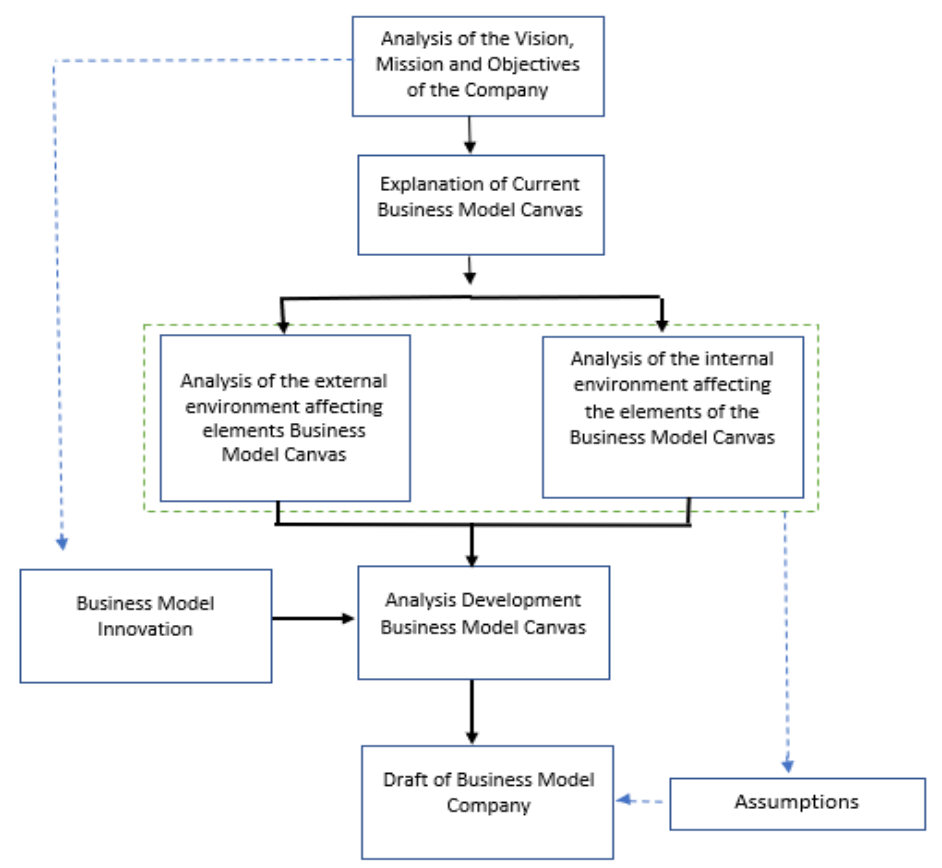

Fig. 8. Framework analysis of a business model.

Based on business model analysis framework on figure 8 above, the processing data and information is required in this study, it can be seen in table 3 .

TABLE III. PROCESSING DATA AND INFORMATION

\begin{tabular}{|c|c|c|c|}
\hline Step Analysis & Data Needed & Data source & $\begin{array}{c}\text { Method of collecting } \\
\text { data }\end{array}$ \\
\hline $\begin{array}{l}\text { Analysis of the Visions, Missions } \\
\text { and Objectives of the Company }\end{array}$ & $\begin{array}{l}\text { Company visions } \\
\text { Company missions } \\
\text { Company Goals } \\
\text { Key Performace Indicators (KPI) of the Company }\end{array}$ & $\begin{array}{l}\text { President Director } \\
\text { Head of the Division of Compliance, Risk } \\
\text { Management and Corporate Planning } \\
\text { Head of Finance and Accounting Division }\end{array}$ & $\begin{array}{l}\text { Study documents } \\
\text { interview }\end{array}$ \\
\hline $\begin{array}{l}\text { Explanation of the elements of the } \\
\text { current business model canvas }\end{array}$ & $\begin{array}{l}\text { customer segments } \\
\text { The value proposition } \\
\text { Channel } \\
\text { Relations with Customers } \\
\text { Source of income } \\
\text { Key resources } \\
\text { core activity } \\
\text { Key partners } \\
\text { The cost structure } \\
\text { Data on points a) to i) above are the current position } \\
\text { datas. }\end{array}$ & $\begin{array}{l}\text { Head of Sales Division } \\
\text { Head of Marketing } \\
\text { Head of Retail Business Operations Division } \\
\text { Head of Corporate Business Operations Division } \\
\text { Head of Human Resources Division } \\
\text { Head of Finance and Accounting Division } \\
\text { Head of Corporate Actuarial Division } \\
\text { Head of the Division of Compliance, Risk } \\
\text { Management and Corporate Planning }\end{array}$ & Study documents \\
\hline $\begin{array}{l}\text { Analysis of external and internal } \\
\text { environment affecting elements } \\
\text { Business Model Canvas } \\
\text { Pestle analysis } \\
\text { Porter's Five Forces Analysis } \\
\text { SWOT analysis }\end{array}$ & $\begin{array}{l}\text { Data from the life insurance industry Life Insurance } \\
\text { Association of Indonesia (AAJI) } \\
\text { Statistics } \\
\text { Shareholder Aspiration of the Ministry of SOEs } \\
\text { Work Plan and Budget in } 2019 \\
\text { Company Long-Term Work Plans } \\
\text { Corporate Financial Statements } \\
\text { Reports Operating Company } \\
\text { Company Management Report }\end{array}$ & $\begin{array}{l}\text { Indonesian Life Insurance Association (AAJI) } \\
\text { Central Bureau of Statistics } \\
\text { Head of Finance and Accounting Division } \\
\text { Head of the Division of Compliance, Risk } \\
\text { Management and Corporate Planning } \\
\text { Head of Corporate Actuarial Division }\end{array}$ & Study documents \\
\hline $\begin{array}{l}\text { Development of a Business Model } \\
\text { Canvas analysis by adding the value } \\
\text { of innovation in the Business Model } \\
\text { Canvas }\end{array}$ & $\begin{array}{l}\text { Related Data: } \\
\text { customer segments } \\
\text { The value proposition } \\
\text { Channel } \\
\text { Relations with Customers } \\
\text { Source of income } \\
\text { Key resources } \\
\text { core activity } \\
\text { Key partners } \\
\text { The cost structure } \\
\text { By adding the value of innovation in the elements of a } \\
\text { Business Model Canvas. }\end{array}$ & $\begin{array}{l}\text { Book } \\
\text { Previous research } \\
\text { Scientific journals } \\
\text { Article } \\
\text { Entire Head of Division (14 people) }\end{array}$ & $\begin{array}{l}\text { Study documents } \\
\text { survey }\end{array}$ \\
\hline
\end{tabular}




\section{RESULTS AND DISCUSSION}

\section{A. Current Company Business Model Canvas}

Assessment of the current business model by using nine (9) elements of the business model canvas as illustrated in Figure 9. Based on Business Model Canvas in Figure 9 can be analyzed that the elements of the revenue stream and cost structure had greatly affects the condition of the company so that the value proposition that should give maximum value for the company in running the business can be constrained by the problems of liquidity, profitability and solvency. The Company had not been able to maximize the group coverage customer segements especially State-Owned Enterprises (SOEs) and handling complaints from consumers, especially in the bancassurance channel has not been handled properly. All three channels of company's distribution had not been maximized well enough especially distribution channels of branch office system (BOS) and employee benefit programs (FMD). In addition, the activities of marketing, sales, management of investment assets, services, asset and liability management and liability management for future policy benefits (LMPMD) had not been able to be managed properly in a professional manner resulting in decreasing of performance which impact on the profitability of the company. Insurance sales agents who are now exist unable to increase the activity of the company's product sales and their performance tends to decrease. Securities firms and investment managers as the company's key partner in managing investments also experience a decline in performance so re-evaluated is needed by the company. Human resources, information technology infrastructure, products and the existing of Branch Office / Regional Office which were spreaded all over Indonesia had not yet supported company's activities in maximum so ineffeciency to the company's cost was occured.

\section{B. SWOT Analysis On BMC PT. XYZ}

1) Strengths: Strengths factor is the main key to the company's success that need to be strengthened and maintained in order to improve company's performance. The strenghts of PT. XYZ can be described as follows:

a) Increased brand awareness: Brand awareness is the ability of consumers to recognize and remember a brand. Brand Awareness is important for a company, because consumers will tend to buy products that are already known or remembered them. Based on a survey which was conducted by an external institution about Top Brand Index, PT. XYZ in 2014 was at rank number 7, 2015 it moved up to 6 and in 2016 rose up to rank 4 and in 2017 still persisted and in 2018 its rank increased to position 2, it is proved that the existence of PT. XYZ more and more be known and remembered by the people of Indonesia, so this can be used as a momentum for PT. XYZ to continue increasing its sales of insurance products in Indonesia, it can be seen in table 4.

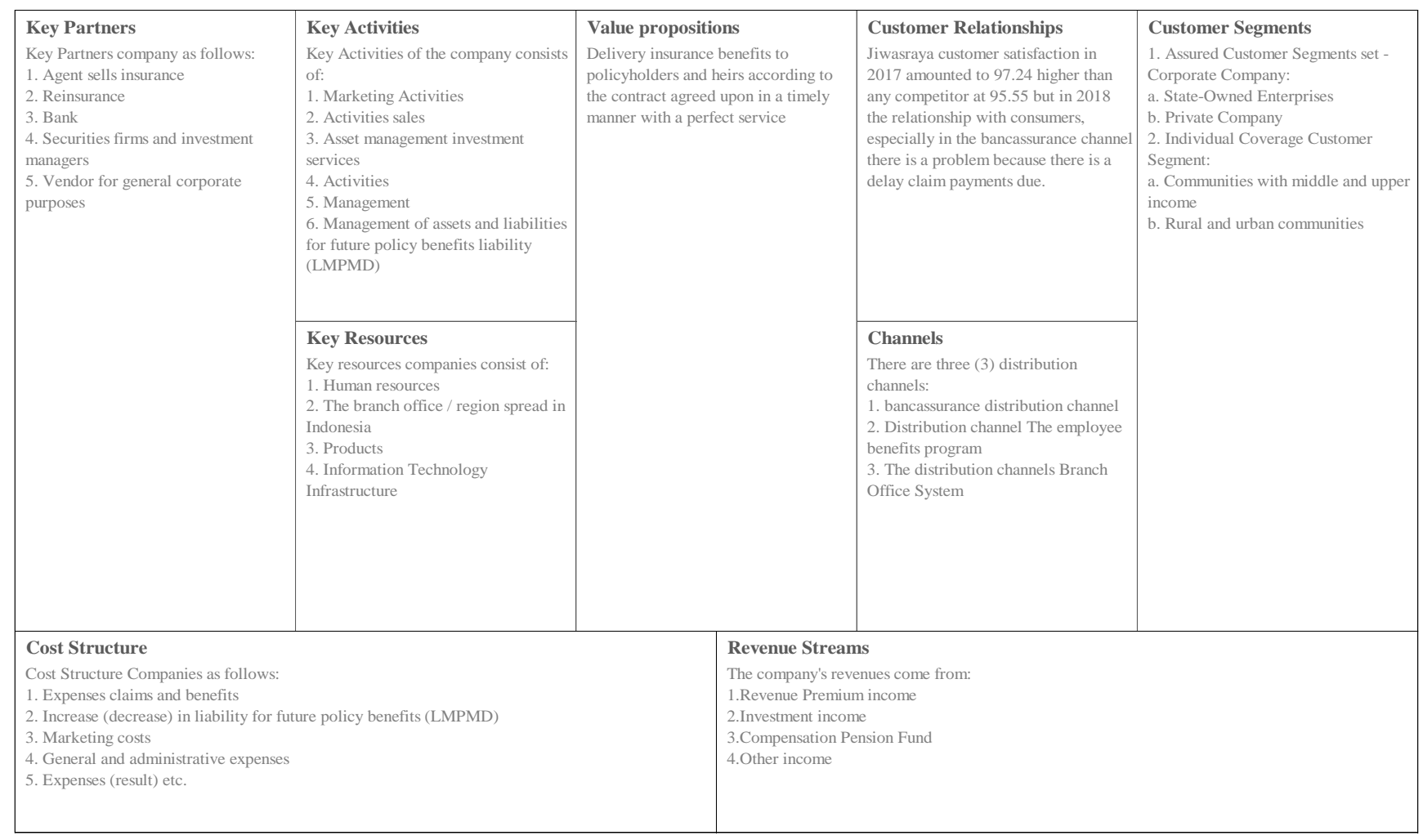

Fig. 9. Current BMC PT. XYZ. 
TABLE IV. BRAND AWARENESS PT. XYZ YEAR 2014 - 2018 [5]

\begin{tabular}{|c|c|c|}
\hline \multicolumn{3}{|c|}{ Top Brand Index 2015} \\
\hline Brand & $T B I$ & Top \\
\hline $\begin{array}{l}\text { Prudential } \\
\text { Life } \\
\text { Assurance }\end{array}$ & $29,60 \%$ & Top \\
\hline $\begin{array}{l}\text { AJB } \\
\text { Bumiputera } \\
1912\end{array}$ & $10,50 \%$ & Top \\
\hline Axa Mandiri & $9,00 \%$ & \\
\hline $\begin{array}{l}\text { Manulife } \\
\text { Indonesia }\end{array}$ & $8,00 \%$ & \\
\hline $\begin{array}{l}\text { AIA } \\
\text { Financial }\end{array}$ & $6,10 \%$ & \\
\hline PT XYZ & $5,80 \%$ & \\
\hline $\begin{array}{l}\text { Allianz Life } \\
\text { Indonesia }\end{array}$ & $5,40 \%$ & \\
\hline \multicolumn{3}{|c|}{ Top Brand Index 2017} \\
\hline Brand & $T B I$ & Top \\
\hline $\begin{array}{l}\text { Prudential } \\
\text { Life } \\
\text { Assurance }\end{array}$ & $31,80 \%$ & Top \\
\hline $\begin{array}{l}\text { AJB } \\
\text { Bumiputera } \\
1912 \\
\end{array}$ & $10,70 \%$ & Top \\
\hline $\begin{array}{l}\text { Manulife } \\
\text { Indonesia }\end{array}$ & $6,10 \%$ & \\
\hline PT XYZ & $5,80 \%$ & \\
\hline $\begin{array}{l}\text { Allianz Life } \\
\text { Indonesia }\end{array}$ & $3,40 \%$ & \\
\hline Axa Mandiri & $3,20 \%$ & \\
\hline
\end{tabular}

\begin{tabular}{|c|c|c|}
\hline \multicolumn{3}{|c|}{ Top Brand Index 2016} \\
\hline Brand & $T B I$ & Top \\
\hline $\begin{array}{l}\text { Prudential Life } \\
\text { Assurance }\end{array}$ & $33,10 \%$ & Top \\
\hline $\begin{array}{l}\text { AJB } \\
\text { Bumiputera } \\
1912\end{array}$ & $11,10 \%$ & Top \\
\hline $\begin{array}{l}\text { Manulife } \\
\text { Indonesia }\end{array}$ & $7,00 \%$ & \\
\hline PT XYZ & $5,80 \%$ & \\
\hline Axa Mandiri & $3,70 \%$ & \\
\hline $\begin{array}{l}\text { Allianz Life } \\
\text { Indonesia }\end{array}$ & $3,20 \%$ & \\
\hline \multicolumn{3}{|c|}{ Top Brand Index 2018} \\
\hline Brand & $T B I$ & Top \\
\hline $\begin{array}{l}\text { Prudential Life } \\
\text { Assurance }\end{array}$ & $29,80 \%$ & Top \\
\hline PT XYZ & $9,00 \%$ & Top \\
\hline $\begin{array}{l}\text { AJB } \\
\text { Bumiputera } \\
1912\end{array}$ & $9,00 \%$ & \\
\hline Axa Mandiri & $8,80 \%$ & \\
\hline $\begin{array}{ll}\text { Allianz Life } \\
\text { Indonesia }\end{array}$ & $6,70 \%$ & \\
\hline & & \\
\hline
\end{tabular}

b) PT. XYZ as a state owned enterprise: The status of SOE becomes a big capital for PT. XYZ to form an image as a life insurance company that is more secure and safe in doing business and become the company's core competencies as the only companies involved in the life insurance industry.

c) Service network that is wide enough: By having 14 Regional Offices, 2 Headquarters, 71 Branch Office and Work Area Units scattered throughout the territory of Indonesia, making PT. XYZ has a strength in terms of distribution network products. In addition to the extensive range also have a positive impact for the policy holder in obtaining a fast and easy service.

2) Weaknesses: Weakness factors are things that cause the failure of the company so that it needs to be improved in order to achieve the corporate objectives. Weaknesses of PT. XYZ can be described as follows:

a) The number and the sales force productivity: With the condition of market penetration is still small and the market continues to evolve, the sales force becomes strategic for the company to increase retail market (individual) for all segments. However, the biggest contribution on the realization of PT. XYZ's premiums achievement is still dominated by bancassurance and group insurance. While on the other hand all of the competitors in this case the joint venture actually rely on agent channels to penetrate and dominate the market share in the premium revenue competition. In terms of the number and agents' productivity of the competitors are better than PT. XYZ's agents. b) The uneven performance of the office and office productivity: In efforts to achieve the target of company's total premium revenue, the existence of Production Offices all over the regions are expected to contribute through the achievement of the set up targets in which it accumulated as the company's premium revenue target. In reality, the performance of the Production Offices was not as the company's expected so that the projected production target was not as planned. The achievement contributions are still dominated by certain offices and bancassurance distribution channels. This is certainly an obstacle for the company to achieve the targets set.

c) Less than optimal education and training of sales force: Education and training for agents is one way to boost sales force's productivity and quality so that they are able to market life insurance products. The education and training system has been arranged in the agency guideliness of PT. $\mathrm{XYZ}$, however it has not run optimally because it still requires effort to introduce the importance of education as well continuing assistance to agents.

d) The balance of the operational costs: Organizations operational working unit (Branch and Regional Office) has not been effective in implementing the strategy and work program that was established by the company. On the other hands the existence of the organization has created overhead costs and imballanced of operating costs compared to premium production that was produced.

e) The low penetration of the market by marketers: The marketers forces that are owned by the company has not been able to penetrate the market that is actually potential due to the lack of optimal education and training agents.

f) The balance of asset liability matching: PT. XYZ has a mismatch in return, duration, and type. The quality of financial assets that is also low and illiquid.

3) Opportunities: The company opportunities in developing its business in the future are wide open which are marked by some of the following:

a) Insurance market potential in Indonesia is still very large: Indonesia's total population of more than 240 million people and with a growth rate of about $1.5 \%$ per year and the penetration rate is still low is a very big market. It is also supported by the high level of development of the insurance industry for about $20 \%$ per year. With the large size and growing market and the degree of market acceptance of insurance products that keeps increasing is an open opportunity for life insurance companies.

b) Increasing public awareness about the importance of insurance: Public awareness of the importance of insurance is developing. Based on data from AAJI that the growth of the insurance policies and the number of insurance policy holders particular the individual sectors was increased every year. Therefore, the company has a product marketing opportunities because it is supported by public awareness about the importance of the insurance that is relatively high as an investment and protection for the family.

c) Insurance knowledge has become part of the educational curriculum: Insurance knowledge edication is currently being carried out at both formal education at middle 
education and higher education levels. This phenomenon is quite good for the insurance companies as a means to further enhance the level of recognition, knowledge and awareness about the importance of insurance so it will be easier for companies to accelerate market penetration.

d) The Social Security program is not enough to provide protection for the public: Based on PT. XYZ's research results with Mark Plus in 2017, the National Social Security System (SJSN) has increased public awareness of the importance of life insurance benefits, however the public is well aware that the Social Security is not enough to provide protection which is an opportunity for the Insurance company to continue to introduce their products to complement the benefits of the Social Security program.

e) Synergy of state owned enterprise: In accordance with the Instruction of the Minister for State Owned Enterprises No. KEP-109 / MBU / 2002 on Synergy Between State Owned Enterprises and the Regulation of the Minister of BUMN number: PER-15 / MBU / 2012 on General Guidelines for Procurement of Goods and Services Enterprise, in 2016 the Ministry of SOE encourages State Owned Enterprises (SOEs) to maintain its commitment to a synergy among SOEs even at a higher level in order to strengthen its position.

4) Threats: The threat of the company in developing its business in the future is characterized by some of the following:

a) Insurance business competition is getting tighter: In the intense of competition, each insurance company tried to do a variety of innovations both in terms of technology, product features up to excellences and ease of services system that provides added value for customers. In response to the competition, PT. XYZ should be more careful in creating a product by seeing the need and customer segmentations and strengthen the services system and the easiness of its access, which currently still considered need to be improved furthermore.

b) The more critical the community and business partners: The more information emerges in each sector and the high demand to provide the commitment and service, especially the insurance sector gives impact of increasing critical consumens in both individual and institutional consumers about the service process that is given by the insurance company. With this condition and many choices of financial planning products has forced the company to have commitment and service that is promised to the consumers in order to maintain the market and develop the market.

c) The substitution of the Bank's products, securities companies, finance companies and insurance losses: As one of financial services company, PT. XYZ is not only competing with other life insurance companies, but also must contend with the Bank, securities companies, finance companies, and insurance.

d) Regulations relating to each sector: With the Law No. 24 of 2011 concerning the establishment of the National Social Security System, through the Social Service Agency (BPJS) for Employment and BPJS for health give obligation consequences for the company to provide the budget for the program. This of course has implicated the insurance companies to penetrate the market, especially to the prospective Policyholder / Policyholder due to financial constraints. In addition, provisions that is oriented on prudence in placement of investment sometimes is not in line with the characteristics of insurance product portfolio that has been held prior to the provision set.

e) National and local political conditions facing the 2019 presidential election: The political dynamics pose a threat in the form of political risk. Political risk is closely linked to the government, the political situation and the security of the state. In general, if the political conditions support the business then the company business process will run well. Political environment that is condusif will lead to a tendency of better improvement in finance and national economy. Instead instability of the political situation both in central and regional level will result in instability of the financial situation and the national economy.

f) Natural disaster: Located in the fire ring area of the world, Indonesia is prone to earthquakes rocked by the tsunami waves. Volcanoes which are found in almost all over the islands also added a series of possible volcanology disasters. Its position on the equator makes Indonesia has only two seasons, sunny and rainy. Sunny can cause dryness also forest fires, while the rainy season usually will cause flooding.

g) Financial technology: Financial technology or fintech, spawned a variety of new modes which are more practical for consumers to access financial products and services. The existence of fintech revolutionized the workings of traditional financial institutions.

h) The uncertainty of the world economic situation and monetary: The uncertainty of the world economic and monetary situations is an event which could not be predicted accurately. But the turmoil in reality will affect the economic and monetary situation of a country. With the situation of global and open economic system then the impact will ultimately affect the situation and the business environment of each country. The changes require each business to be set up in anticipation through mitigation of the assumptions, planning and the right strategy so that the company's target can still be achieved.

Based on the description in the analysis of the strengths and weaknesses can be concluded that the company should be able to maximize the power that is owned such as brand awareness which is still good in the eyes of consumers, the company's status as a state and service network which spread all over Indonesia is still a high selling point for the company. In addition, the company has to fix the existing weaknesses such as the diminishing number and productivity of sales force in which resulting in uneven performance and productivity of branches / regions, the imbalance of operating costs with the expected results and the need for significant improvements in maintaining the balance of assets and liabilities because it gives a significant impact on the liquidity and solvency of the company. Furthermore, based on the description on the analysis of opportunities and threats can be concluded that the company still has a huge opportunity in developing its business in the future because of the potential insurance market in Indonesia is still very large, and the synergy of State Owned Enterprise that became a driving force for company to win the competition in the life insurance industry in Indonesia. The 
existence of the threat factors should be anticipated by the company by fixing the existing weaknesses as long as it is related to products and technologies to provide more benefits for the consumer.

In accordance with the SWOT analysis above, the identification of the impact on BMC PT. XYZ as presented in Figure 10.

From this analysis and giving attention to the influence of external and internal factors and the need for innovation of business model that can increase the value of the company and be able to overcome the problems of profitability, solvency and liquidity of the company in line with the implementation of the Visions, Missions and Objectives of the company as presented in Figure 11. The increasing in revenue stream and the decreasing in cost structure become the primary thing that needs to be solved, thus creating company's business model that can overcome the main problems that is faced.

The Company has its strength on a joint coverage customer segments and there are not many competitors in this segment. The market potential in this sector is very important to get by the company to generate cash flow to help the company to get out of liquidity problem. Therefore, the company needs to establish an organization that focus on the management of corporate clients. The organization is in charge of managing corporate customers in an integrated way so the potential of corporate customers can be explored to the fullest and be served to perfection and has a clear and measurable key performance indicator (KPI).

Companies must be able to create maximum policy benefit for consumers according to their needs and provide maximum services to achieve high customer satisfaction and provide assurance to customers that their fund or investments in insurance product that they have purchased safely managed by PT. XYZ. Liquidity, solvency and profitability issues are the top priorities that must be resolved by PT. XYZ with the full support of the in charge shareholders, in this case the Ministry of State-Owned Enterprises (SOEs).

To reduce the cost of the company, the existence of a number of branches / regions that have less performance needs to be evaluated existence. It needs a workload assessment and cost and benefit analysis of all operational elements associated branch / region. Branch offices throughout the city with regional offices proposed to be merged. Need reinforcement for Employee Benefit Plans distribution channel that still promises a profitable business for the company. Bancassurance distribution channels geared to managing the business for the product is not guaranteed.

Relationship with customers, especially customers of bancassurance saving plan needs to be repaired by establishing an integrated, centralized and well-structured claims services center, so that the handling of claims can be carried out properly and measurably. Call Center should be utilized as much as possible as a medium for companies in dealing with complaints claim properly.

revenue sources of the company are expected coming from joint coverages (corporate customers) with premium rates that has been adjusted to the company's ability to manage its investment assets so that the premium income generated may provide profits for the company. Corporate business is still promising for the company because the company's status is a
State Owned Enterprise makes the company as an option for corporation to hand over the management of pension and insurance benefits to PT. XYZ.

The existing Insurance sales agents need to be re-assessed in order to obtain high quality insurance sales agents who can deliver product information properly. This need to be done to minimize the occurrence of miss-selling that can harm both the customer and the company. The Change in the organizational structure in 2019 led to the employees of PT. XYZ as per December 31, 2018 amounted to 1,069 was considered as too many, so that re-assessment was necessary in order to choose productive and qualify employees. The existence of branches / areas that are very much also needs to be evaluated by the management to obtain the optimal cost and benefit.

Sales and marketing activities should be strengthened by the company to increase the rate of customer satisfaction and interest in the products sold by the company as before. Digital technology in sales activities should be developed by the company to regain a significant premium income. The need to recruit new experts in the field of sales and marketing in order to create a new culture of sales. In addition, an expert in the field of actuarial needs to be added by 2 (two) of FSAI (actuary) to improve the quality in the calculation of liabilities for future policy benefits (LMPMD) cause these activities have a significant impact on the profitability and solvency of the company.

The agreement with the key partners who have been cooperating with the company need to be re-evaluated and updated as it should be. The agreement with the Bank and the Corporate Customer which promising benefits over the company's ability needs to be negotiated to each institution by the company for reviewing the very high benefits because if it still remains, will lead to the risk of default payment in the future.

Cost structure which allocated to the premium rates needs to be re-evaluated by the company to anticipate the negative spread. Products that still valid and sell by the company need to be repricing so the negative spread condition will not happen again. The efficiency of the company's operating costs needs to be done by improving business process so it could be more effective and efficient and cut unnecessary operating costs. The shrinking number of employees can be done by enhancing the role of information technology to facilitate the implementation of the new business process.

Development of company's Business Model Canvas in Figure 11 explains that the customer segments of the company can be level up with a focus on customer segments of group coverage customer by forming organizations specialized in the management of corporate customers, especially state-owned enterprises with the synergy pattern. In addition, relationships with customers, especially customers of saving plan on the bancassurance distribution channel needs to be repaired by establishing a unified claims service center, centralized and systemized can be maximized as a medium for the company in dealing with claim complaints properly. Insurance sales agent has also been re-assessment to obtain quality insurance sales agent, reinsurance companies as well as banks and securities firms and investment managers also have renewed the agreement in order to improve its performance. This will encourage the increasing of sales and marketing activities with digital technology that is supported by experts in sales and 
actuary sectors as to improve the quality of enterprise services to consumers. In addition, the application of portfolio management in the management of investment assets is applied to support the balance of assets and liabilities that the company's solvency can be maintained properly. To ensure the success of all activities above, it need to be supported by human resources with high competency, the infrastructure of information technology that can be more productive with digital technology, quality products that are able to provide profit for the company and the availability of Regional Offices / Branches with a new structure and more efficient. The strength of the company's distribution channel is maximized to increase company's business value that generate profits for the company. The company's cost structure has been calculated according to the allocation in premium rates so that the negative spread does not occurred and the products that was sold has been repricing so the negative spread will not have happened again. In addition, the main thing that becomes the concern of the company to improve the company's revenue which are premium incomes and investment returns is done by increasing the insurance premium revenue of group customers by using synergy of State Owned Enterprise concept and restructuring of the investment portfolio and maximizing the returns of DPLK services. Overall activities in the business model canvas elements above will create value in delivery insurance benefits to policyholders and their heirs according to the contract that have been agreed in a timely manner with perfect service so that maximum satisfaction for consumers is realized. The emergence of confidence from customers that funds or investments have been entrusted to PT. XYZ will be safely managed by the company as well and also the liquidity, solvency and profitability problems can be solved by PT. XYZ with the full support of the in charge shareholders which is the Ministry of SOEs would make PT. XYZ become the largest life insurance company in Indonesia once more.

Development of the company's Business Model Canvas can be implemented by the company in order to realize the visions, missions and goals of the company with the assumptions and policies that PT. XYZ must be able to maintain the company's going concern with full support of the Ministry of SOEs as the proxy of shareholders, in addition to the commitment of the Managing Directors and senior top managers who are one level below the directors who become agents of changes in implementing new business models so that the process of changes can run well. To support all of that, it is necessary to change the organizational structure that adjusts to the changes in business processes so that acceleration of the company's performance happened.

Regarding the commitment of President Director in making changes related to the visions, missions and objectives of the company, interviews with the President Director has been conducted with the result that the Director believes that the leaders of the PT. XYZ has the competence to be able to make changes so that the problem of PT. XYZ can be resolved. In addition, it also has to do change readiness survey to give 19 (nineteen) questions to 14 (fourteen) of head divisions as shown in Appendix 4 with the result that these questions response is $53 \%$ agree, $44 \%$ strongly agree, $1 \%$ disagree and $2 \%$ neutral. From the survey results we can conclude that $97 \%$ of the Head of Division stated readiness and agree with the changes made by the company to maintain the continuity of the company's business. It can be seen on figure 10 and figure 11 .

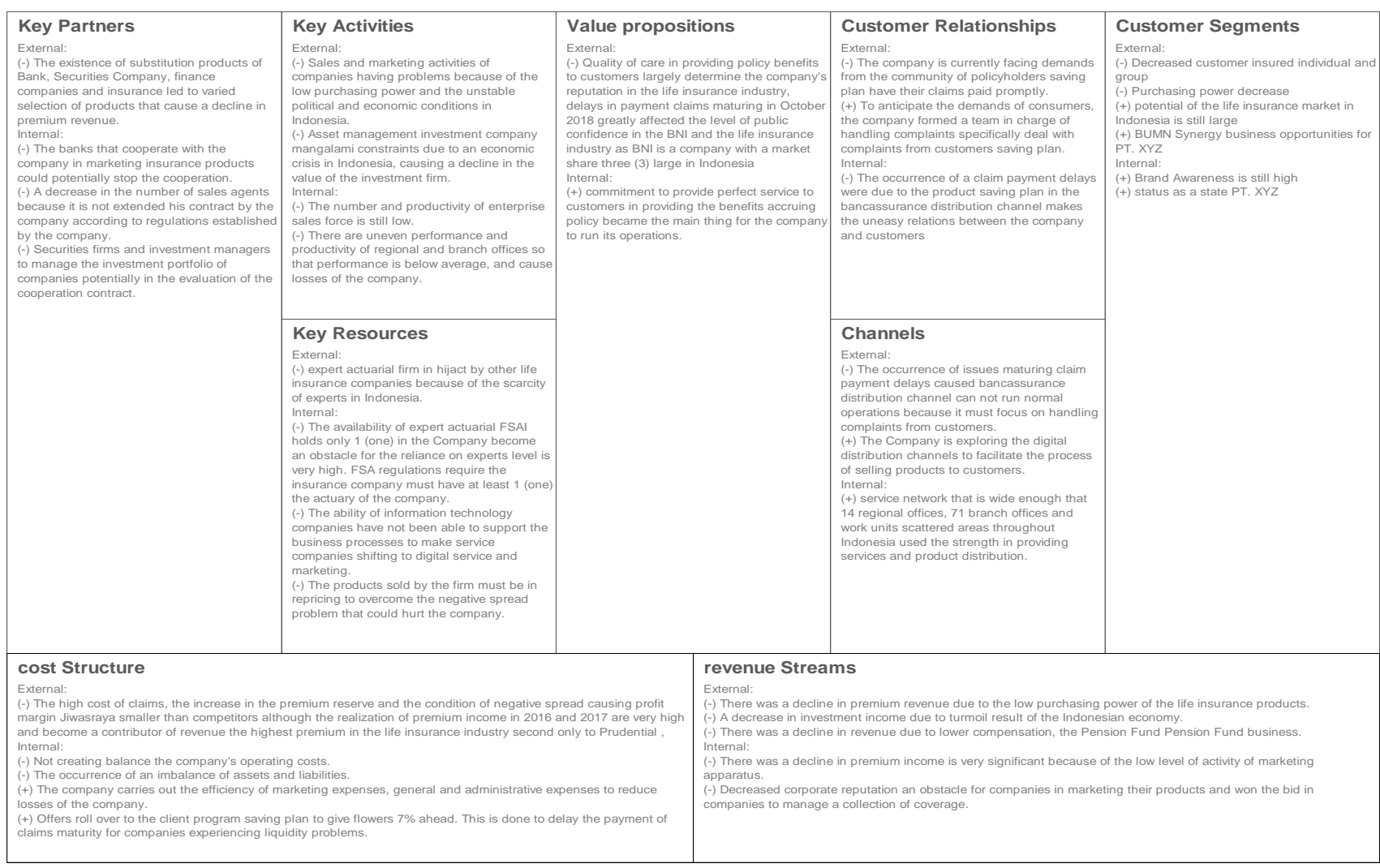

Fig. 10. Influence of external and internal factors against BMC PT. XYZ. 


\begin{tabular}{|c|c|c|c|c|c|}
\hline \multirow[t]{2}{*}{$\begin{array}{l}\text { Key Partners } \\
\text { Key Partners company as follows: } \\
\text { 1. Agents insurance salesman who has } \\
\text { reassesment } \\
\text { 2. Bank: the renewed agreement } \\
\text { 3. Reinsurance: the renewed } \\
\text { agreement. } \\
\text { 4. Securities firms and investment } \\
\text { managers who have updated their } \\
\text { covenants and in evaluating its } \\
\text { performance. } \\
\text { 5. Vendor for general corporate } \\
\text { purposes that have evaluated its } \\
\text { performance. }\end{array}$} & $\begin{array}{l}\text { Key Activities } \\
\text { Key Activities of the company consists } \\
\text { of: } \\
\text { 1. Sales and marketing activities with } \\
\text { digital technology } \\
\text { 2. Recruitment of experts in the sales } \\
\text { sector and actuaries can create a new } \\
\text { culture in the sales process. } \\
\text { 3. Asset management investment with a } \\
\text { good portfolio management } \\
\text { 4. Activities of professional services } 5 . \\
\text { Management of assets and liabilities } \\
\text { better and measurable. } \\
\text { 6. Management of liabilities for future } \\
\text { policy benefits (LMPMD) are more } \\
\text { qualified. }\end{array}$ & \multirow{2}{*}{\multicolumn{2}{|c|}{$\begin{array}{l}\text { Value propositions } \\
\text { The creation of value creation in the } \\
\text { download delivery of insurance } \\
\text { benefits to policyholders and heirs } \\
\text { according to the contract agreed upon } \\
\text { in a timely manner with a perfect } \\
\text { service to realize maximum } \\
\text { satisfactionserta their confidence of } \\
\text { customers that the funds or investments } \\
\text { that they entrust to secure Jiwasraya } \\
\text { managed by the company. The problem } \\
\text { of liquidity, solvency and profitability } \\
\text { can be solved by Jiwasraya with the } \\
\text { full support of the power of the } \\
\text { shareholders of the Ministry of SOE. }\end{array}$}} & $\begin{array}{l}\text { Customer Relationships } \\
\text { Relationship with customers, especially } \\
\text { customers saving plan on the } \\
\text { bancassurance distribution channel } \\
\text { needs to be repaired by establishing a } \\
\text { claims service center unified, } \\
\text { centralized and tersistem well so that } \\
\text { the handling of the claim can be done } \\
\text { well and scalable. Call centers can be } \\
\text { maximized as a medium for companies } \\
\text { in dealing with complaints claim } \\
\text { properly. }\end{array}$ & \multirow[t]{2}{*}{$\begin{array}{l}\text { Customer Segments } \\
\text { 1. Focus on Customer Segment Insured } \\
\text { set - Corporate Company by } \\
\text { establishing organizations specifically } \\
\text { on the management of corporate } \\
\text { clients: } \\
\text { a. State Owned Enterprises (BUMN) } \\
\text { b. Private Company } \\
\text { 2. Individual Coverage Customer } \\
\text { Segment: } \\
\text { a. Communities with middle and upper } \\
\text { income } \\
\text { b. urban communities }\end{array}$} \\
\hline & $\begin{array}{l}\text { Key Resources } \\
\text { Key resources companies consist of: } 1 . \\
\text { The human resources with high } \\
\text { competence. } \\
\text { 2. The branch office / region spread in } \\
\text { Indonesia with new, more efficient } \\
\text { structure. } \\
\text { 3. Information Technology } \\
\text { Infrastructure more productive with } \\
\text { digital technology. } \\
\text { 4. A quality product that is able to } \\
\text { generate profits for the company. } \\
\text { 5.Agen quality insurance salesman. }\end{array}$ & & & $\begin{array}{l}\text { Channels } \\
\text { There are three (3) distribution } \\
\text { channels: } \\
\text { 1. bancassurance distribution channels } \\
\text { geared to manage the business for } \\
\text { products that are not under warranty } \\
\text { and business alliances. } \\
\text { 2. The distribution channel of } \\
\text { employee benefits programs with high } \\
\text { profitability of the distribution channel } \\
\text { 3. Branch Office System evaluated } \\
\text { according anaysis workload and cost } \\
\text { and benefit to the business. }\end{array}$ & \\
\hline \multicolumn{3}{|c|}{$\begin{array}{l}\text { cost Structure } \\
\text { Cost Structure company has been calculated according to the allocation in premium rates so that no } \\
\text { negative spread and the products sold have carried repricingagar negative spread condition does not } \\
\text { happen again with the following objectives: } \\
\text { 1. Expenses claims and benefits have been managed well } \\
\text { 2. Increase (decrease) in liabilities future policy benefits (LMPMD) has been managed well } \\
\text { 3. marketing costs have been calculated according to standard activity } \\
\text { 4. general and administrative expenses have been calculated according to standard activity } \\
\text { 5. Costs (result) others can be managed properly. }\end{array}$} & \multicolumn{3}{|c|}{$\begin{array}{l}\text { The company's revenues come from: } \\
\text { 1. Premiums: more than premium PK with premium rates that have been adapted to generate profit, } \\
\text { corporate business remains promising for the company because the company's status is a state that can } \\
\text { take advantage of synergy to increase its premium income. } \\
\text { 2. Income on investment: it needs to restructure the investment portfolio. } \\
\text { 3. Revenue compensation DPLK with maximum results } \\
\text { 4. Other revenues were further optimized. }\end{array}$} \\
\hline
\end{tabular}

Fig. 11. Development of BMC PT. XYZ.

\section{CONCLUSION}

Based on the above, it can be deduced as follows:

- The Company has formulated a canvas element within the current business model that has been mapped some things that need to be improved for future development of the company's business model.

- External and internal environment of the company are very influential to the elements in the canvas business model of the company, it is reflected in decreasing in of revenue streams and rising cost structure that affected the amount of loss of the company in 2018 and the liquidity problem that had caused a delay in the payment of claims of customers in the distribution channel of bancassurance.

- Development canvas company's business model has been arranged with attention to the visions, missions, corporate objectives and business strategies that run in 2019 to solve the problems of liquidity, profitability and solvency as well as adding value innovation to strengthen the elements canvas business model primarily on the revenue stream and cost structure thereby increasing the value propositions and value creation in running the company's operations.

\section{REFERENCES}

[1] IMF, "UN and World Bank, 2011.'. Supporting the Development of More Effective Tax Systems," Report to the G-20 Development Working Group, 2016

[2] Koran Jakarta, "Capaian Investasi 2018 Melesat," [Online]. Retrieved from http://www.koran-jakarta.com/capaian-investasi-2018-meleset/

[3] A. Osterwalder and P. Yves, Business Model Generation. Jakarta: PT. Elex Meda Komputindo Kelompok Gramedia, 2012.

[4] W.C. Kim and R. Mauborgne, Blue Ocean Strategy. USA: Harvard Business Publishing, 2005.

[5] Top Brand, "Top Brand Index," [online]. Retrieved from https://www.topbrand-award.com/top-brand-index/ 